\author{
Marcin PILARCZYK ${ }^{1}$ \\ Bohdan WEGGLOWSKI ${ }^{2}$
}

\title{
ANALIZA CIEPLNO-WYTRZYMALOŚCIOWA ROZRUCHU KOTŁA PAROWEGO NA PRZYKŁADZIE KOTŁA OP-650
}

\begin{abstract}
W artykule przedstawiono analizę typowego rozruchu kotła parowego OP-650. Omówiono zmiany w czasie ciśnienia oraz temperatur na zewnętrznej powierzchni walczaka i komory wylotowej pary świeżej. Wymienione parametry mierzono za pomocą systemu monitorującego SCADA. Na podstawie analizy odwrotnej przewodzenia ciepła określono temperaturę wewnętrznej powierzchni ścianek kotła. Dla otrzymanych zmian temperatury oraz ciśnienia możliwe było obliczenia obwodowych i zredukowanych naprężeń, które porównano z normami dotyczącymi projektowania grubościennych elementów ciśnieniowych. Określone wartości naprężeń obwodowych i zredukowanych były 2-5 razy niższe od wartości naprężeń dopuszczalnych. Na tej podstawie stwierdzono, że możliwe jest przyspieszenie rozruchu kotła OP-650.
\end{abstract}

Słowa kluczowe: kocioł energetyczny, naprężenia cieplne, szybkość nagrzewania, elementy kryterialne, rozruch

\section{Wprowadzenie}

W związku z rosnącym wykorzystaniem odnawialnych źródeł energii, wśród których coraz większy udział mają fermy wiatrowe, zmienia się struktura mocy dyspozycyjnej. Ze względu na dużą niestabilność elektrowni wiatrowych zwiększa się przedział mocy szczytowych i podszczytowych, co prowadzi do powstania znacznych dysproporcji obciążenia Krajowego Systemu Elektroenergetycznego w ciągu doby [1]. Sytuacji nie poprawia fakt, że ze względu na wiek i dyrektywy unijne spora ilość jednostek zostanie wyłączona. Istnieje poważna obawa, że ubytek mocy mogą nie zrównoważyć nowo budowane bloki energetyczne. Należy również zwrócić uwagę na fakt, że odbudowa mocy jest związana głównie z budową dużych kotłów na parametry nadkrytyczne o wysokiej

\footnotetext{
${ }^{1}$ Autor do korespondencji: Marcin Pilarczyk, Politechnika Krakowska, Al. J. Pawła II 37, 31-864 Kraków, tel. 1262835 59, e-mail:marcin.pilarczyk@mech.pk.edu.pl

2 Bohdan Węglowski, Politechnika Krakowska, Al. J. Pawła II 37, 31-864 Kraków, 1262835 56, e-mail: weglowski@mech.pk.edu.pl
} 
sprawności, a te uzupełniają moc podstawową. Polskie Sieci Energetyczne dostrzegając ten problem, czyli możliwość wystąpienia deficytu wymaganej przez operatora nadwyżki mocy, organizują przetargi na zakup usługi interwencyjnej rezerwy zimnej.

Z tego powodu warto przeanalizować rozruchy kotłów pod kątem możliwości szybszego ich wprowadzania do ruchu. Niezbędne jest określenie cieplno-wytrzymałościowych warunków pracy ciśnieniowych grubościennych elementów kotłów w trakcie nieustalonych warunków występujących w trakcie rozruchów i wyłączania kotła z ruchu.

\section{Opis kotła OP-650}

Polska energetyka zawodowa oparta jest przede wszystkim na pracy kotłów wysokiej wydajności, opalanych pyłem węglowym. Analizie zostaną poddane wybrane elementy ciśnieniowe kotła parowego OP-650, który jest kotłem opromieniowanym, dwuciągowym, jednowalczakowym o naturalnej cyrkulacji wody, opalanym pyłem węgla kamiennego. Główne parametry kotła OP-650 zostały przedstawione w tabeli 1 .

Tabela 1. Podstawowe parametry pracy kotła OP-650

Table 1. Basic operating parameters of the OP-650 steam boiler

\begin{tabular}{|c|l|c|c|}
\hline L.p. & parametr pracy kotła & wartość & jednostka \\
\hline 1 & wydajność maksymalna trwała & 650 & $\mathrm{t} / \mathrm{h}$ \\
\hline 2 & $\begin{array}{l}\text { wydajność przy której osiąga się przegrzew pary } \\
\text { pierwotnej } 540^{\circ} \mathrm{C}\end{array}$ & 200 & $\mathrm{t} / \mathrm{h}$ \\
\hline 3 & ciśnienie obliczeniowe kotła & 16,1 & $\mathrm{MPa}$ \\
\hline 4 & ciśnienie robocze w walczaku & 15,5 & $\mathrm{MPa}$ \\
\hline 5 & temperatura nasycenia w walczaku & 343 & ${ }^{\circ} \mathrm{C}$ \\
\hline 6 & ciśnienie pary świeżej & 13,7 & $\mathrm{t} / \mathrm{h}$ \\
\hline 7 & $\begin{array}{l}\text { temperatura pary świeżej za IIII }{ }^{\circ} \text { przegrzewacza gro- } \\
\text { dziowego }\end{array}$ & 540 & ${ }^{\circ} \mathrm{C}$ \\
\hline 8 & ciśnienie obliczeniowe przegrzewacza wtórnego $^{\circ}$ & 3,0 & $\mathrm{MPa}$ \\
\hline 9 & $\begin{array}{l}\text { ciśnienie pary wtórnej za III }{ }^{\circ} \text { przegrzewacza kon- } \\
\text { wekcyjnego }\end{array}$ & 2,4 & $\mathrm{MPa}$ \\
\hline 10 & $\begin{array}{l}\text { temperatura pary wtórnej za } \text { III }^{\mathrm{o}} \text { przegrzewacza kon- } \\
\text { wekcyjnego }\end{array}$ & 535 & ${ }^{\circ} \mathrm{C}$ \\
\hline
\end{tabular}




\section{Analiza pracy kryterialnych elementów kotła}

Najbardziej istotnym (z uwagi na wysokie naprężenia termiczne) etapem eksploatacji kotła jest jego rozruch. W ciągu roku każdy kocioł jest wielokrotnie uruchamiany po awaryjnych bądź planowanych wyłączeniach z ruchu. Z uwagi na szeroki zakres zmiany ciśnienia i temperatury, akumulację zmiany w proporcjach przejmowanego ciepła przez poszczególne powierzchnie ogrzewalne, niektóre elementy kotła pracują w okresie rozruchowym w nietypowych warunkach $[2,7,9,13]$. Zakres i dynamika zmian tych wielkości zależą od początkowego stanu cieplnego kotła, którego rozruch ma zostać przeprowadzony. Ze względu na złożoność nieustalonych procesów przepływowo-cieplnych, grubościenne elementy ciśnieniowe kotła są poddawane znacznym obciążeniom naprężeniami cieplnymi pochodzącymi od różnicy temperatury na grubości ścianki oraz na obwodzie [12]. W miarę wyrównywania się temperatur naprężenia cieplne zmniejszają się a naprężenia pochodzące od ciśnienia rosną osiągając stan stabilny charakterystyczny dla pracy kotła ze stałą wydajnością np. nominalną. W niniejszym podrozdziale zostanie przeprowadzona analiza pracy $\mathrm{w}$ stanie nieustalonym tzw. kryterialnych elementów kotła energetycznego, do których należą m.in. walczak i komora wylotowa pary świeżej. $Z$ uwagi, iż są to elementy grubościenne, limitują one szybkość rozruchu oraz wyłączenia kotła. W tabeli 2 podane zostały wymiary, maksymalne parametry pracy oraz własności wytrzymałościowe analizowanych elementów.

Tabela 2. Stałe materiałowe przyjęte do obliczeń

Table 2. The material constants used in the calculations

\begin{tabular}{|l|c|c|c|c|c|c|c|c|}
\hline Element kotla & $\begin{array}{c}\mathbf{p}_{\max } \\
\mathbf{M P a}\end{array}$ & $\begin{array}{c}\mathbf{t}_{\mathbf{m a x}} \\
{ }^{\circ} \mathbf{C}\end{array}$ & $\begin{array}{c}\mathbf{t}_{\text {obl }} \\
{ }^{\circ} \mathbf{C}\end{array}$ & $\begin{array}{c}\mathbf{E}_{\text {vobl }} \\
\mathbf{M P a}\end{array}$ & $\begin{array}{c}\boldsymbol{\sigma}_{\text {0.2vobl }} \\
\mathbf{M P a}\end{array}$ & $\begin{array}{c}\beta_{\text {Lvobl }} \\
\mathbf{1 / K}\end{array}$ & $\begin{array}{c}\mathbf{a}_{\text {vobl }} \\
\mathbf{m m}^{2} / \\
\mathbf{m i n}\end{array}$ & $\begin{array}{c}\sigma_{\text {minB }} \\
\mathbf{M P a}\end{array}$ \\
\hline $\begin{array}{l}\text { Walczak 1800x115 } \\
\begin{array}{l}\text { 18GMNA } \\
(15 \mathrm{NCuMNb})\end{array}\end{array}$ & 15,5 & 330 & 252 & $1,94 \cdot 10^{5}$ & 334 & $1,31 \cdot 10^{-5}$ & 570 & 560 \\
\hline $\begin{array}{l}\text { Komora wylotowa } \\
\text { pary świeżej 377x50 } \\
\text { 12H1MF }\end{array}$ & 13,5 & 540 & 410 & $1,87 \cdot 10^{5}$ & 213 & $1,38 \cdot 10^{-5}$ & 480 & 440 \\
\hline
\end{tabular}




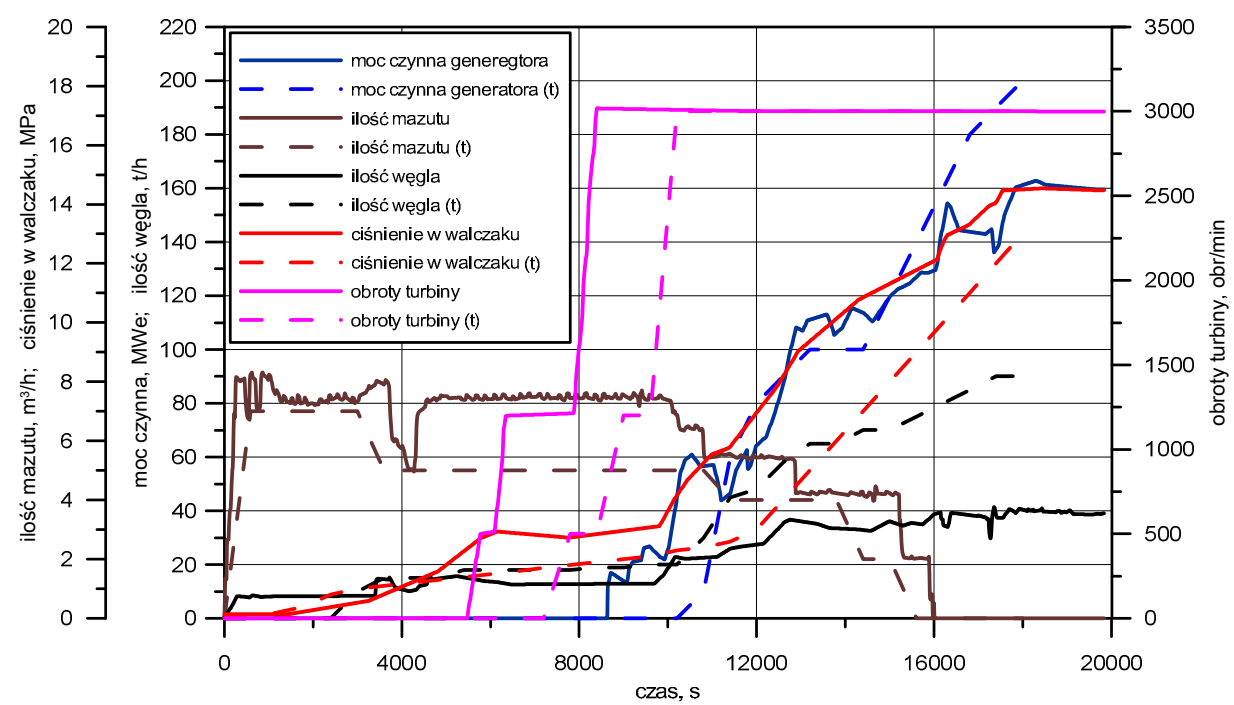

Rys. 1. Przykład typowego rozruchu kotła OP-650. Porównanie rzeczywistych wartości podstawowych parametrów z teoretycznymi (t) (opis krzywych w legendzie)

Fig. 1. An example of typical start-up of OP-650 boiler. Comparison of real values of basic parameters with theoretical ones ( $t$ ) (the description of curves in the legend).

Na rys. 1 przedstawiono typowy rozruch ze stanu zimnego kotła OP-650. Przebiegi poszczególnych wielkości tak jak: ilość paliwa rozpałkowego (mazutu), węgla, moc czynna generatora, obroty turbiny oraz ciśnienie w walczaku uzyskano przy wykorzystaniu systemu monitorowania SCADA i zestawiono z ich teoretycznymi odpowiednikami. Czas rozruchu, liczony od momentu zapłonu pierwszego palnika mazutowego do momentu osiągnięcia stałej mocy czynnej generatora, wynosi ok. 5h. Warto zaznaczyć, że osiągnięta moc generatora jest mniejsza od nominalnej mocy - 160MW jest mniejsza od nominalnej $225 \mathrm{MW}$. Analizując rzeczywiste zużycie mazutu, widać, że po upływie 4000 sekund został włączony dodatkowy palnik mazutowy. Pozwoliło to na nieznacznie szybsze zwiększenie ciśnienia w walczaku oraz na wcześniejsze uruchomienie turbozespołu. Niemniej jednak warto zaznaczyć, że od momentu osiągnięcia przez turbinę prędkości obrotowej na poziomie $3000 \mathrm{obr} . / \mathrm{min}$ zużycie paliwa podstawowego, jakim jest węgiel, jest wyraźnie mniejsze, niż wynikające $\mathrm{z}$ przebiegu teoretycznego. Jednym z następstw tego stanu rzeczy jest mniejsza moc czynna generatora, która wynikała najprawdopodobniej z bieżącego zapotrzebowania mocy w sieci elektroenergetycznej. W tabeli 3 przedstawiono maksymalne i minimalne naprężenia oraz dopuszczalne szybkości nagrzewania i ochładzania poszczególnych elementów na początku i końcu rozruchu bądź odstawiania kotła. 
Tabela 3. Obliczone dopuszczalne szybkości zmian temperatury i dopuszczalne naprężenia

Table 3. The calculated allowable rates of temperature variation and allowable stresses

\begin{tabular}{|l|c|c|c|c|c|c|}
\hline Element kotła & $\begin{array}{c}\sigma_{\text {mini }} \\
\text { MPa }\end{array}$ & $\begin{array}{c}\text { Szybkość } \\
\text { MPa } \\
\text { Magrzewa- } \\
\text { nia na } \\
\text { początku } \\
\text { rozruchu } \\
\text { K/min }\end{array}$ & $\begin{array}{c}\text { Szybkość } \\
\text { nagrze- } \\
\text { wania na } \\
\text { końcu } \\
\text { rozruchu } \\
\text { K/min }\end{array}$ & $\begin{array}{c}\text { Szybkość } \\
\text { chłodzenia } \\
\text { na początku } \\
\text { odstawiania } \\
\text { K/min }\end{array}$ & $\begin{array}{c}\text { Szybkość } \\
\text { chłodzenia } \\
\text { na końcu } \\
\text { odstawiania } \\
\text { K/min }\end{array}$ \\
\hline $\begin{array}{l}\text { Walczak 1800x115 } \\
\begin{array}{l}\text { 18GMNA } \\
(15 N C u M N b)\end{array}\end{array}$ & -198 & 511 & 2,5 & 6,4 & $-2,5$ & $-6,4$ \\
\hline $\begin{array}{l}\text { Komora wylotowa } \\
\text { pary świeżej 377x50 } \\
\text { 12H1MF }\end{array}$ & -192 & 312 & 9,4 & 15,3 & $-9,4$ & $-15,3$ \\
\hline
\end{tabular}

Wyniki te uzyskano z przeprowadzonych obliczeń zgodnie z normą EN 12952-3 [3] przy założeniu, że stopień zużycia materiału nie może przekroczyć 40\% dla 2000 cykli rozruchowych ze stanu zimnego. Stan ten odpowiada sytuacji, gdy nie występuje nadciśnienie pary w walczaku, a temperatura czynnika jest niższa od $80^{\circ} \mathrm{C}$ [14]. Warto zaznaczyć, że obliczone dopuszczalne szybkości nagrzewania i ochładzania są znacząco wyższe od wartości dopuszczalnych zawartych w instrukcji obsługi kotła OP-650 [4]. Instrukcja przewiduje, że maksymalna szybkość zmiany temperatury dla walczaka niezależnie od bieżącej temperatury nie może przekraczać $1 \mathrm{~K} / \mathrm{min}$, a dla kolektora wylotowego pary świeżej od 3 do $5 \mathrm{~K} / \mathrm{min}$. W kolejnych podrozdziałach zostanie przeprowadzona analiza pracy wybranych elementów kotła podczas analizowanego rozruchu. Zostanie również omówiona metodyka naprężeń na przykładzie walczaka kotła OP-650.

\subsection{Walczak}

Walczaki kotłów energetycznych należą do jednych z najważniejszych i najdroższych elementów ich konstrukcji. Ze względu na swoją grubościenną budowę oraz pełniącą funkcje w kotle, jako miejsce powstawania pary świeżej w parowniku dochodzi do znacznych naprężeń termicznych. Dodatkowo króćce, licznie występujące w walczakach, przyczyniają się do koncentracji naprężeń, co powoduje przy niewłaściwym prowadzeniu rozruchów i odstawień kotła, trudne bądź niemożliwe do naprawy pęknięcia np. w okolicach rur opadowych. Na rys. 3 zostały przedstawione przebiegi temperatur zewnętrznej powierzchni walczaka $w$ trakcie rozruchu kotła OP-650. Pomiar obejmował 7 punktów pomiarowych rozmieszczonych co $30^{\circ}$ na połowie obwodu walczaka począwszy od dolnej (punkt 1) do górnej (punkt 7) tworzącej. Zarejestrowane przebiegi temperatur pokazują, że różnice występujące przy kołowoniesymetrycznym nagrzewaniu tego elementu są nieznaczne. Jedyny znaczący 
wzrost charakterystycznej różnicy temperatury $\left(\mathrm{T}_{7}-\mathrm{T}_{1}\right)$ nastąpił w momencie, gdy para wodna intensywnie się skraplała na powierzchni wewnętrznej walczaka, której temperatura była niższa od temperatury nasycenia przy aktualnym ciśnieniu. Powodowało to szybsze ogrzewanie części parowej, gdyż współczynnik wnikania ciepła dla kondensującej pary jest wielokrotnie wyższy, od współczynnika wnikania ciepła w obszarze wody. Instrukcja kotła OP-650 [4] dopuszcza maksymalną różnicę temperatury pomiędzy dolną, a górną tworzącą walczaka na poziomie $50 \mathrm{~K}$. Porównując tą wartość z przebiegami temperatur uzyskanymi z pomiarów można stwierdzić, że przez większą część rozruchu kotła nie została ona przekroczona.

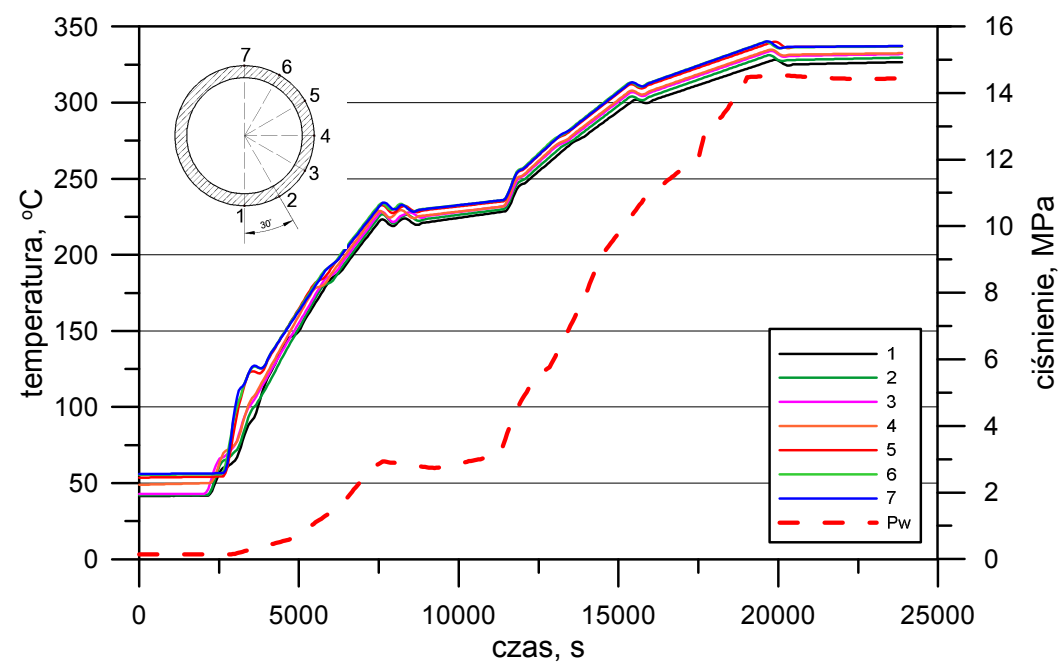

Rys. 2. Przebieg zmian ciśnienia i zmierzonych temperatur na zewnętrznej powierzchni walczaka

Fig. 2. Thevariation of pressure and temperatures measured on the outer surface of boiler drum

Bazując jedynie na pomiarze temperatury na powierzchni zewnętrznej walczaka można wyznaczyć w trybie on-line czasowo-przestrzenne pole temperatury na grubości elementu za pomocą odwrotnej metody przewodzenia ciepła. Zaletą tej metody jest to, że nie wymaga ona zadania warunków brzegowych cieplnych dla wewnętrznej powierzchni walczaka [15]. W literaturze $[10,11]$ zostało zaprezentowane praktyczne wykorzystanie metody odwrotnej przewodzenia ciepła dla monitorowania stanów naprężeń elementów ciśnieniowych dużych kotłów energetycznych. Przy znanym polu temperaturowym, można wyznaczyć lokalne wartości naprężeń obwodowych za pomocą metody elementów skończonych dla powierzchni wewnętrznej. Zastosowanie metody elementów skończonych lub bilansowej metody elementów skończonych do analiz termiczno-wytrzymałościowych elementów ciśnieniowych podczas rozruchu 
kotła przedstawiono w pracy $[5,6,9,16]$. Przebieg naprężeń obwodowych na wewnętrznej powierzchni walczaka przedstawia rys. 3 .

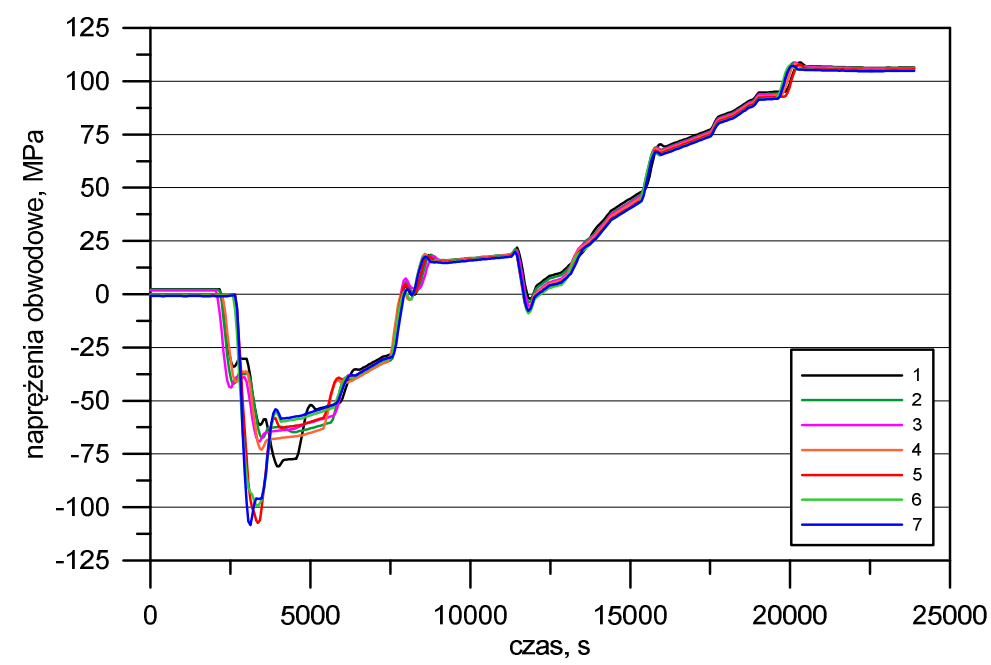

Rys. 3. Naprężenia obwodowe na powierzchni wewnętrznej walczaka

Fig. 3. The circumferential stresses on the inner surface of boiler drum

Ujemna wartość naprężeń obwodowych świadczy o tym, że wewnętrzna powierzchnia walczaka jest poddawana ściskaniu. Spowodowane jest to kondensacją pary, która powoduje intensywne ogrzewanie części parowej walczaka co obrazują przebiegi temperatury dla punktów pomiarowych nr 5, 6 i 7 . W początkowej fazie rozruchu naprężenia obwodowe mają charakter termiczny i są wywołane charakterystycznymi różnicami temperatur na grubości ścianki elementu oraz pomiędzy „górą i dołem” walczaka, które można zaobserwować na rys. 2. Po wyrównaniu temperatur na obwodzie walczaka naprężenia obwodowe mają charakter mechaniczny i są wywołane ciśnieniem wewnętrznym. Co do wartości bezwzględnej naprężenia obwodowe przekraczają nieznacznie $100 \mathrm{MPa}$, co $\mathrm{w}$ porównaniu $\mathrm{z}$ naprężeniami dopuszczalnymi, wyznaczonymi zgodnie z normą EN 12952-3 [3] i zestawionymi w tabeli 3, jest wartością mniejszą od 2 do 5 razy. Istnieje zatem możliwość szybszego rozruchu z uwagi na naprężenia występujące $\mathrm{w}$ walczaku, co potwierdzają również przebiegi naprężeń zredukowanych wyznaczone za pomocą wytężeniowej hipotezy HuberaMisesa-Hencky'ego (HMH) i przedstawione na rys. 4. 


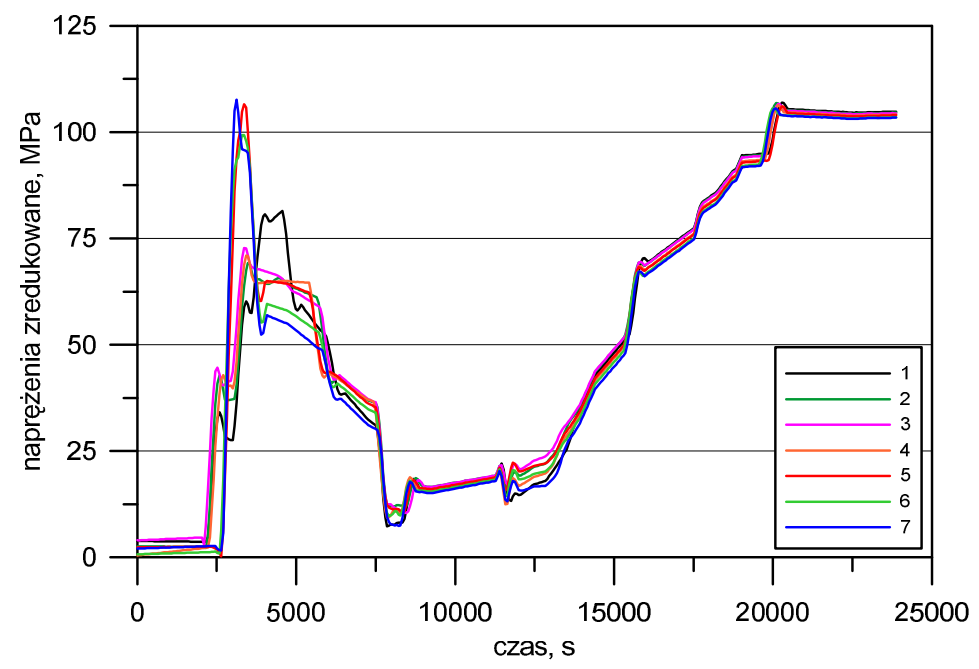

Rys. 4. Naprężenia zredukowane na powierzchni wewnętrznej walczaka

Fig. 4. The equivalent stresses on the inner surface of boiler drum

\subsection{Komora wylotowa pary świeżej}

Podstawowe dane dotyczące komory wylotowej pary świeżej zamieszczono $\mathrm{w}$ tabeli 2 . W przeciwieństwie do walczaka, komora ta pracuje $\mathrm{w}$ warunkach pełzania tj. powyżej temperatury granicznej. W nominalnych warunkach pracy występuje w niej tylko para, zatem w trakcie rozruchu i odstawiania naprężenia wywołane kołowo-niesymetrycznym nagrzewaniem lub ochładzaniem praktycznie nie występują, a zmierzone temperatury na połowie obwodu nie wykazują dużych różnic między sobą, tak jak to jest przedstawione na rys. 5.

Przebieg naprężeń obwodowych wyznaczony w analogiczny sposób jak w przypadku walczaka prezentują podobne wartości w trakcie całego cyklu rozruchowego i zostały przedstawione na rys. 5 . 


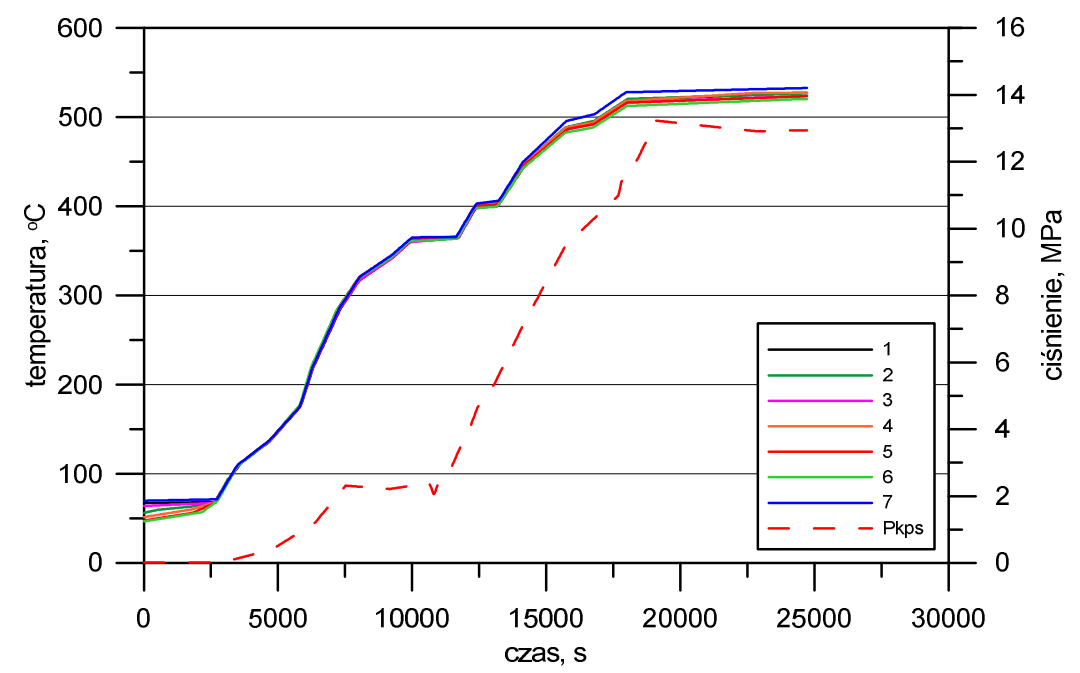

Rys. 5. Przebieg zmian ciśnienia i zmierzonych temperatur na zewnętrznej powierzchni kolektora wylotowego pary świeżej

Fig. 5. Thevariation of pressure and temperatures measured on the outer surface of the live steam outlet header

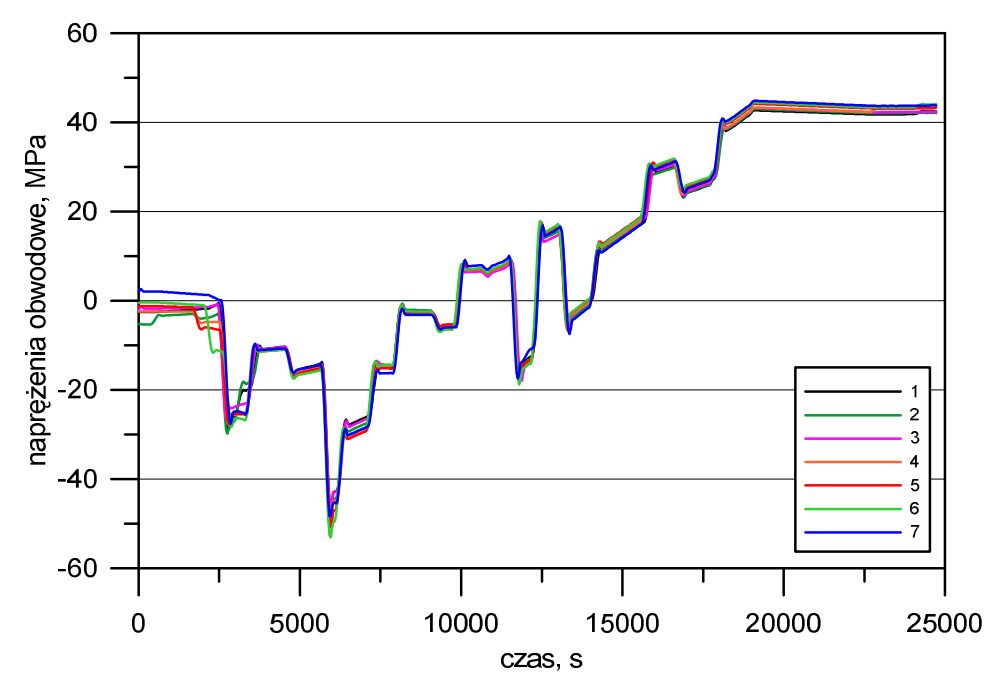

Rys. 6. Naprężenia obwodowe na wewnętrznej powierzchni kolektora wylotowego pary świeżej

Fig. 6. Thecircumferential stresses on the inner surface of live steam outlet header

Jedyne zauważalne różnice występują w początkowej fazie rozruchu, gdy kolektor jest ogrzewany przez kondensującą na całym obwodzie parę wodną. Osiągnięcie temperatury nasycenia wewnętrznej powierzchni następuje jednak 
po krótkiej chwili i kołowa-niesymetryczność pola temperatur jest spowodowana zaleganiem kondensatu w dolnej części komory. Kondensat ten jednak szybko odparowuje. Zatem naprężenia obwodowe dla każdego z punktów pomiarowych temperatury wykazują bardzo zbliżony charakter, a ich wartości względem wartości dopuszczalnych, podanych w tabeli 3, są wyraźnie niższe. Naprężenia zredukowane uzyskane za pomocą hipotezy H-M-H także wykazują niewielkie różnicę dla punktów 1-7, największe rozbieżności występują w początkowej fazie rozruchu kotła. Zarówno wartości naprężeń zredukowanych jak i obwodowych są znacznie mniejsze od naprężeń dopuszczalnych (patrz tabela 3).

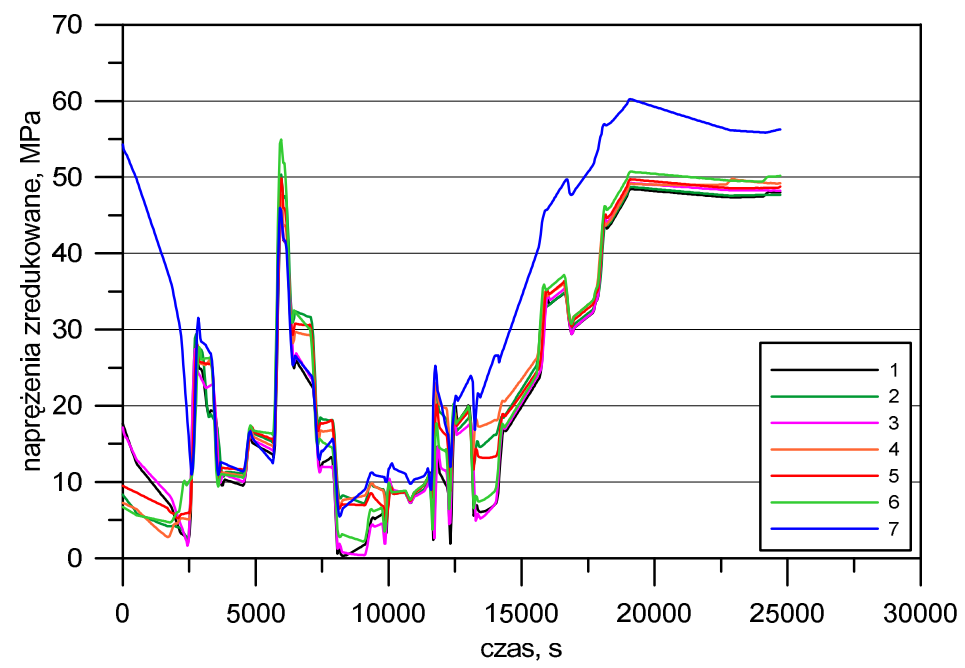

Rys. 7. Naprężenia zredukowane na wewnętrznej powierzchni kolektora wylotowego pary świeżej

Fig. 7. The equivalent stresses on the inner surface of live steam outlet header

W celu skrócenia czasu rozruchu kotła jest zalecane nagrzewanie i ochładzanie elementów ciśnieniowych kotła parowego, tak aby sumaryczne naprężenia cieplne i naprężenia pochodzące od ciśnienia utrzymywać na możliwie wysokim poziomie zbliżonym do dopuszczalnego [8].

\section{Wnioski}

Celem rozruchu kotła jest uzyskanie znamionowych parametrów czynnika roboczego i takiego obciążenia, aby olejowe palniki rozpałkowe pracowały tylko przez okres niezbędny do osiągnięcia stabilnej pracy kotła na paliwie zasadniczym (pyle węglowym), co pozwala na zminimalizowanie strat rozrucho- 
wych oraz na oszczędność drogiego paliwa rozpałkowego. Analiza typowego rozruchu kotła parowego dużej wydajności pokazuje, że istnieją realne możliwości przyśpieszenia cyklu rozruchowego kotłów energetycznych. Porównanie wartości dopuszczalnych naprężeń obliczonych według normy EN 12952-3 dla każdego $\mathrm{z}$ elementu $\mathrm{z}$ wartościami zmierzonymi pokazuje, że rozruch nie jest prowadzony na tyle szybko na ile byłoby to możliwe. Jedynym momentem, w którym notowane są wyraźne wzrosty naprężeń jest początek rozruchu, podczas którego para skrapla się na zimnych ściankach rozważanych elementów ciśnieniowych, intensyfikując tym samym proces wymiany ciepła. Wraz ze wzrostem parametrów pracy naprężenia występujące w elementach grubościennych zależą głównie od ciśnienia, którego wartość można łatwo kontrolować.

\section{Literatura}

[1] Cisek P.: Elektryczne ogrzewanie akumulacyjne budynków, Ciepłownictwo, Ogrzewnictwo, Wentylacja, 6 (2014) 218-225.

[2] Cwynar L.: Rozruch kotłów parowych, WNT, Warszawa 1981.

[3] European Standard, EN 12952-3, Water-tube boilers and auxiliary installations Part 3: Design and calculation for pressure parts. CEN - European Committee for Standarization, rue de Stassart 36, B-1050 Brussels, 25. July 2001.

[4] Instrukcja kotła OP-650.

[5] Majcher A., Węglowski B., Ocłoń P.: monitoring of the stress state in the boiler drum using finite element method, Adv. Mat. Research, 875 (2014) 1176-1182.

[6] Ocłoń P., Taler J.: Mixed finite volume and finite element formulation: Linear Quadrilateral Elements, Encyclopedia of Thermal Stresses, Edited by Richard B. Hetnarski, Springer, Dordrecht Heidelberg New York London, vol. 6, pp. 3070-3086.

[7] Taler J., Duda P., Węglowski B.: Thermal-strength monitoring and remnant lifetime assessment of pressure components of power steam boilers (Chapter 6), Diagnostics of new-generation thermal power plant, PAN, Gdańsk 2008, pp. 252-338.

[8] Taler J., Dzierwa P.: Optymalizacja nagrzewania elementów ciśnieniowych kotła w czasie rozruchu, Zagadnienia projektowania i eksploatacji kotłów i turbin do nadkrytycznych bloków węglowych, Praca zbiorowa pod redakcją G. Kosmana, A. Rusina, J. Talera, M. Pawlika, Wydawnictwo Politechniki Śląskiej, Gliwice 2010.

[9] Taler,J., Ocłoń P.: Finite Element Method in Steady-State and Transient Heat Conduction, Encyclopedia of Thermal Stresses, Edited by Richard B. Hetnarski, Springer, Dordrecht Heidelberg New York London, vol. 4, pp. 1604-1633.

[10] Taler J., Węglowski B., Sobota T., Jaremkiewicz M., Taler D.: Inverse space marching method for determining temperature and stress distributions in pressure components. In: Marco Aurèlio dos Santos Bernardes (ed) Developments in heat transfer, Intech, Rijeka 2011, pp. 273-292.

[11] Taler J., Węglowski B., Zima W., Grądziel S., Zborowski M.: Analysis of thermal stresses in boiler drum during start-up, Trans. ASME, J. Pressure Vessel Technol., 121 (1999) 84-93.

[12] Węglowski B.: Blok ograniczeń termicznych energetycznych kotłów parowych, Zeszyty naukowe Politechniki Krakowskiej seria Mechanika, Kraków 2001. 
[13] Węglowski B.: Monitorowanie pracy walczaka kotła OP-230, Systemy, technologie i urządzenia energetyczne, Monografia pod redakcją J. Talera, Wydawnictwo Politechniki Krakowskiej, Kraków 2010, Tom I, str. 193-202.

[14] Węglowski B.: Rozruch i wyłączanie kotła z ruchu, Procesy cieplne i przepływowe w dużych kotłach energetycznych, Monografia pod redakcją Jana Talera, Wydawnictwo Naukowe PWN, Warszawa 2011, str. 385-404.

[15] Węglowski B., Ocłon P.: Analysis of operating conditions for pressure components of steam boilers, Rynek Energii, 6 (2012) 99-106.

[16] Węglowski B., Ocłoń P., Pilarczyk M., Majcher A.: Stress analisys for the start-up operation on the example of OP-210 boiler drum, Problemy Eksploatacji, 2 (2013)19-28.

\section{The thermal and structural analysis of steam boiler start-up on the exam- ple of OP-650 power unit}

\section{S u m m a r y}

The paper presents the analysis of a typical start-up of power boiler OP-650. The time variations of pressure and wall temperatures measured on the outer surface of pressure elements (boiler drum, live steam outlet header) were discussed. These process parameters were obtained using SCADA monitoring system. Based on the solution of the inverse heat conduction problem the temperatures of the inner wall surface were determined. For the obtained temperature and pressure variations it was possible to calculate the circumferential and equivalent stresses that were compared with the design standards for the thick-walled pressure components. The determined circumferential and equivalent stresses values were 2 to 5 times lower than the allowable stresses. Based on the comparison it was concluded that there is the possibility of accelerated start-up procedure for boiler OP-650.

Keywords: steam boilers, thermal stresses, heating rate, criterial elements, boiler start-up

DOI: $10.7862 / \mathrm{rm} .2014 .8$

Otrzymano/received: 15.05 .2014

Zaakceptowano/accepted: 27.05.2014 